\title{
COVID-19: The Invisible Massacre of the Elderly and the Possible Professional Liabilities
}

\author{
Andrea Cioffi \\ Doctor in Training-Department of Anatomical, Histological, Forensic and Orthopaedic Sciences, \\ Sapienza University of Rome, Italy
}

\begin{abstract}
The elderlies are probably the most affected by the COVID-19 Pandemic. Despite this, the measures aimed at preventing the serious consequences that this health emergency may have on the elderly are still inadequate. This study analyses the effects of the current pandemic on elderlies and debilitated patients. In addition, the study focuses on the legal implications of the damages that the elderlies are suffering in this worldwide emergency.
\end{abstract}

Keywords: COVID-19; Sars-CoV-2; Health Policy; Elderly; Medical Liability; Ethics in Policy; Legal Medicine.

\section{Introduction}

COVID-19 Pandemic has created serious health, social and economic damage worldwide. Deaths due to COVID-19 continue to increase with serious repercussions. National Health Systems are implementing preventive and curative strategies aimed at containing infections and related deaths.

In this context of emergency is developing silently, especially in Europe, a serious emergency in the emergency: the massacre of the elderly in elderly homes. The numbers are worrying and there are still no appropriate strategies and solutions to contain the problem. The problem is so serious and urgent that the WHO regional director for Europe, Hans Kluge, called the Situation "deeply concerning". This statement is based on dramatic data, in fact as of April 13, more than $55 \%$ of deaths in Ireland were linked to long-term care facilities. In France, as of April 15, more than 49\% of deaths were linked to care facilities, while in Belgium more than $49 \%$ of the 4,857 deaths linked to Covid- 19 as

\section{Corresponding Author:}

\section{Andrea Cioffi}

Viale Regina Elena, 336. 00161, Rome. Italy. e-mail: an.cioffi19@gmail.com of April 16 were in care homes. Care England, Britain's largest representative body for care homes, said that estimates based on some of the death rates since April 1 suggested up to 7,500 people in British care homes may have died of the virus, five times the official estimate. Moreover, Covid-19 related deaths in care homes in Portugal and Spain were 33\% and 53\% respectively ${ }^{1}$.

Therefore, in many European Countries, half of the deaths for COVID-19 are elderly residents in the care homes.

Also, in Italy, where $35 \%$ of the population is over 65, there is a serious emergency related to COVID-19 related deaths in Elderly homes. The worrying number of deaths in health care facilities for the elderly has led the Italian Higher Institute of Health to carefully monitor the situation. From the careful analysis of the available data (however provisional) it has emerged that the number of deaths in Elderly homes is increasing exponentially in a worrying way, especially in 3 Italian regions (Lombardy, Piedmont and Emilia Romagna) ${ }^{2}$.

Legal Implications: The dramatic data of infections and deaths related to COVID-19 in care homes are even more worrying if analyzed in relation to the possible causes involved. In fact, there is growing concern around the world that these deaths were somehow predictable and preventable. 
With regard to predictability, it is considered that long before the pandemic declaration it was already clear that the severe form of COVID-19 developed more easily in the elderly and that deaths were age-related ${ }^{3}$. This has been confirmed by subsequent studies which have shown a higher mortality rate in older people 4 . So, it was absolutely predictable that this pandemic would hit the elderly and debilitated more severely.

With regard to the avoidability of the numerous deaths in the elderly homes, it is important to stress that in recent weeks there have been numerous concerns in the health management of care homes. In fact, reports from health workers and relatives of victims are increasing exponentially. The criticism concerns the approach, considered ineffective and deontologically incorrect, in the field of prevention and monitoring of COVID-19 among the elderly ${ }^{5,6}$. The problems concern the non-use of personal protective equipments (which often would not even have been provided to operators), the insufficient monitoring of body temperature and symptoms typical of COVID-19 (resulting in inadequate epidemiological and statistical classification of infections) and, even erroneous death certificates.

In this context, full of doubts still not clarified on the civil and criminal responsibilities of some elderly homes, in some states, as in Italy, we think about the possibility of creating a legal immunity for health professionals engaged in the battle against the COVID-197,8.

The purpose of a possible legal shield would be to protect doctors and all health professionals who could be targeted by legal proceedings for professional liability (related to the emergency COVID-19).In fact, the risk of a possible legal immunity is that the possible responsibilities of the health directorates of hospitals and homes are not properly investigated and eventually sanctioned. In fact, there are situations in which there have been questionable choices of elderly homes and care homes in the management of elderly and debilitated patients, as stated by the President of the National MedicineBoard ${ }^{9}$.

\section{Conclusions}

It can be said that the problem of the protection of the elderly in care homes has been greatly underestimated in many Countries. The consequences of the spread of COVID-19 among weak and elderly people were, at least in part, predictable and avoidable. The responsibility of society as a whole can be seen in the poor and superficial management of vulnerable people. Unfortunately, this pandemic has shown us that the care, energy and resources we devote to the elderly are inadequate and inappropriate. It will probably be necessary to reform the entire organization of the elderly homes, often understood exclusively as a place where "abandon" individuals no longer "useful" and difficult to manage. It is hoped that the current concept of elderly homes will evolve to co-housing (managed by health professionals). As for psychiatric patients ${ }^{10-14}$, even for elderly people who are not self-sufficient it is necessary to overcome the logic of institutionalization to implement the logic of "social healthcare". All this must be aimed at not abandoning the vulnerable, but at ensuring all the necessary protection.

It is precisely in situations such as this - in which appropriate health policies become necessary - that society can demonstrate humanity, efficiency and effectiveness, or incivility and anti-ethical utilitarianism.

Financial Disclosure: There is no financial disclosure.

Conflict of Interest: None to declare.

Ethical Clearance: Not required.

\section{References}

1. Rthk.hk. WHO warns of "human tragedy" at elderly homes. Available from: https://news.rthk.hk/rthk/ en/component/k2/1522396-20200424.htm

2. ISS. Survey nazionale sul contagio COVID-19 nelle strutture residenziali e sociosanitarie. Available from: https://www.epicentro.iss.it/coronavirus/pdf/ sars-cov-2-survey-rsa-rapporto-3.pdf

3. Zhang JJ, Dong X, Cao YY, Yuan YD, Yang YB, Yan YQ et al. Clinical characteristics of 140 patients infected with SARS-CoV-2 in Wuhan, China. Allergy. 2020 Feb 19. doi: 10.1111/ all.14238. Online ahead of print.

4. Verity R, Okell LC, Dorigatti I, Winskill P, Whittaker C, Imai $\mathrm{N}$ et al. Estimates of the severity of coronavirus disease 2019: a model-based analysis. Lancet Infect Dis. 2020 Jun;20(6):669677.doi: 10.1016/S1473-3099(20)30243-7.

5. Financial Times. UK care homes struggle with wave of Covid-19 cases. Available from: https:// www.ft.com/content/574ca84a-e735-4e42-8faf62c641953efc 
6. Brett Arends. Opinion: The nursing home COVID-19 tragedy - how did this happen? Available from: https://www.marketwatch.com/ story/the-nursing-home-covid-19-tragedy-howdid-this-happen-2020-04-24

7. Gazette (The Law Society). Covid-19: 'Grant doctors immunity from clin neg claims'. Available from: https://www.lawgazette.co.uk/news/ covid-19-grant-doctors-immunity-from-clin-negclaims/5103941.article

8. SIMLA. Responsabilità medica e Covid-19: verso una moratoria?Available from: https://www. simlaweb.it/2020/03/29/responsabilita-medica-ecovid-19-verso-una-moratoria/

9. FNOMCeO. Covid-19, Anelli (FNOMCeO): "Ritirare gli emendamenti 'colpo di spugna' per la responsabilità delle strutture. Dopo più di due mesi sono ancora molti i medici a mani nude contro il virus". Available from: https:// portale.fnomceo.it/covid-19-anelli-fnomceoritirare-gli-emendamenti-colpo-di-spugna-per-laresponsabilita-delle-strutture-dopo-piu-di-duemesi-sono-ancora-molti-i-medici-a-mani-nudecontr/

10. Hobbs C, Newton L, Tennant C, Rosen A, Tribe K.
Deinstitutionalization for long-term mental illness: a 6-year evaluation.Aust N Z J Psychiatry. 2002 Feb;36(1):60-6.

11. Bersani G, Rinaldi R, Iannitelli A. Psychiatry and bioethics: a critical relationship, an incentive to reflect.RivPsichiatr. 2020 Mar-Apr;55(2):57-58. doi: $10.1708 / 3333.33019$.

12. MontanariVergallo G, Zaami S, Di Luca NM, Bersani G, Rinaldi R. Italian Law N. 24/2017 on Physicians' Criminal Liability: A Reform That Does Not Solve the Problems of the Psychiatric Practice. RivPsichiatr. 2017 Nov-Dec;52(6):213-219. doi: 10.1708/2846.28724.

13. Anastasia A, Coletti C, Cuoco V, Quartini A, Urso S, Rinaldi R et al. Demographic variables, clinical aspects, and medicolegal implications in a population of patients with adjustment disorder. Neuropsychiatr Dis Treat. 2016; 12: 737-743.

14. Anastasia A, Cataldo D, Coletti C, Di Falco R, Centracchio I, Del Nero P et al. Socio-demographic, Clinical and Criminological Features of a Population Discharged From Forensic Hospital and Admitted to Neuropsychiatric Clinic, in Scheme of Restriction of Freedom. Riv Psichiatr. 2014 SepOct;49(5):235-42. doi: 10.1708/1668.18266. 